\title{
Can Accounting Practices, Interests, and Motivations Increase Work Readiness for Prospective Accountants?
}

\author{
Salma Faundria Nagari ${ }^{1,}$ Surya Seno Pamungkas ${ }^{2,}$ Ika Kristianti $^{3 *}$ \\ ${ }^{1,2,3}$ Satya Wacana Christian University \\ "Corresponding author.Email: ika.kristianti@uksw.edu
}

\begin{abstract}
Prospective accountants need to prepare a strategy in choosing a career path before becoming an accountant. One strategy that can be done is to improve the quality of human resources. As a school that has a goal to prepare students who are ready to work, the Vocational High School (SMK) majoring in accounting is also one of the cornerstones for the world of work to design prospective accountants. The purpose of this study is to analyze accounting practices, student interests and student motivation in increasing readiness to become prospective accountants. This research is a quantitative study, using a regression test. This study uses a population of all vocational students majoring in accounting in Salatiga. The sample of this study used 66 respondents from SMKs in Salatiga. Sample selection is based on purposive sampling. The results of this study are the second hypothesis is accepted, while the first hypothesis and third hypothesis are rejected. Interest is still a strong driving force, and as an encouragement to an accountant, it is believed that he will optimize the work readiness of the respondents.
\end{abstract}

Keywords: Work Readiness, Interest, Motivation, Accounting Practices

\section{INTRODUCTION}

The increasing competition as accountants in this era of ASEAN Economic Community (AEC) has become crucial for education. There is a need of maximum preparation to be fulfilled by the prospective accountants. AEC does not only open trade flows of goods or services, but trade flows of professionals (Satria, 2019). Prospective accountants need to prepare strategies in choosing career paths before becoming accountants. One of the strategies that can be accomplished is to improve the quality of human resources. Increasing human resources can be pursued by building character through education, one of which is vocational education.

Vocational high school or known in Bahasa Indonesia as Sekolah Menengah Kejuruan (SMK) is designed to prepare students to step into the world of work. SMK is required to produce graduate students who have the ability to face the world of work, adequate skills, and work attitudes that are in accordance with the workplace (Muayati \& Margunani, 2014). In the learning process, the learning content used by SMK is practical methods. The ability to apply accounting theories that are obtained in the classroom into practice is one of the competencies that graduated students from vocational school carry with them. The benchmarks of success for these competencies are often assessed by the community as the readiness to show their abilities according to national or even international standards.

SMK needs to collaborate with various parties such as business or industry, universities, district or city governments and community in order to improve the quality of its graduates (Muayati \& Margunani, 2014). It is completed to help students understand the theories that they have gotten in the classroom, therefore they are ready to enter the world of work. Besides, students' readiness needs to arise from within. This kind of readiness will help them improve their abilities when they step into the world of work. In the city of Salatiga, there are several vocational high schools which offer accounting practices in their learning curriculum. One of these schools is SMK Diponegoro Salatiga which owns a showroom business called "BC Mart". The showroom is managed by students who practice accounting, marketing, and management. Based on an initial interview with one of the respondents, SMK Diponegoro has the courage to expand by opening a second branch of the showroom, which is located quite far from the school, ever since the growing development 
of BC Mart. Nevertheless, the management of the retail store is still in the hands of students who perform their internship there.

Besides SMK Diponegoro which has a business unit, SMK Negeri 1 Salatiga also has a Koperasi which is an Indonesian community based economy. Koperasi is a business unit that manages and develops small industries. Koperasi runs by SMK Negeri 1 Salatiga is an independent business unit that not only sells school's necessities but also provides daily necessities. Schools that apply technology and innovation can improve learning to be more effective and efficient so that it benefits both students and teachers at these schools (Dockter, 2012). The method applied by SMK Diponegoro Salatiga is in accordance with the Indonesian Ministerial Regulation (Permenperin, 2017) which states that industrial work practices carried out by SMK students in industrial companies and / or companies are part of the vocational education curriculum in order to master skills or expertise in the industrial sector.

In order to understand accounting material properly, it is necessary to provide assignments that can be done individually or in groups in a practical simulation (Popa, Stănilă, \& Ponorîcă, 2012). The practice of applying accounting at SMK Diponegoro Salatiga is carried out by accounting management that takes place at "BC Mart". Meanwhile, the practice of applying accounting at SMK Negeri 1 Salatiga is carried out by management at koperasi. The computerized system applied to BC Mart can improve students' ability to carry out operational accounting concepts like in the real world of work. This is reinforced by other findings in a research by (Popa et al., 2012), interest is an internal factor that affects students' understanding of the material being studied. Slameto also states in (Deswita \& Dahen, 2015) that interest is a tendency to pay attention to and hold on to some desires. However, research conducted by (Susanti, Rispantyo, \& Kristianto, 2017) states that interest in learning does not have a significant effect on accounting understanding, but learning interest has a positive value, which means that the greater interest in learning a student will result in an increase in understanding of accounting. This is reinforced by the statement from Maryati (2017), namely that people who have an understanding of accounting are clever and truly understand accounting.

In a research done by Ezeagba (2014), it states that teachers must motivate students who understand well the accounting material presented in class. This motivation can be accomplished by establishing good communication so the guidance of showroom management can run smoothly. In practice conducted at BC Mart and Koperasi, it aims to prepare students majoring in accounting to be ready to compete in the world of work. Firdaus (2013) states that work readiness requires working skills or soft skills and good conduct at work. Having good work readiness requires several conditions including expertise according to the field, broad insight, understanding in thinking, and a good personality. These conditions will make a person feel comfortable in the work done so that he or she will achieve success (Agusta, 2015).

Based on data from the Central Statistics Agency No. 41/05 / Th. XXII, May 6, 2019, which shows that the highest open unemployment rate is SMK graduates at $8.63 \%$, and one of the contributors to the open unemployment rate is SMK graduates majoring in accounting. Therefore, this study aims to analyze accounting, student interest and student motivation in increasing readiness to become prospective accountants.

\section{LITERATURE REVIEW}

\subsection{Job Readiness of Accountant Candidates}

Work readiness for SMK graduates is an important matter as to achieve a good career. This provision is obtained from schools that provide accounting practice media as adequate teaching materials for students so that students have skills and independence. According to Mu'ayati (2014), several things that affect the work readiness of a vocational high school graduate are industrial work practices, productive practical dictates, and simultaneous work interest. Indonesia's unstable economic growth affects accounting graduates to work not in accordance with their major even though there are many opportunities for accounting careers especially becoming professional accountants (Anna \& Rahayu, 2012). The number of accountants in Indonesia is still relatively small compared to Indonesia's population and current economic growth (Satria, 2019).

Professional accountants always uphold the code of ethics of the accounting profession, this requires skill and experience. Institutions that provide high experience in the accounting profession are public accounting firms, corporate internal accountants, and government accountants with ethical habits that are implemented as SOPs (Yunanda \& Majid, 2011). An experienced accountant can determine policies as a consideration for decision making in maintaining wealth, determine the effectiveness and efficiency of the system, and determine the procedures for company activities based on the company's financial statements (Satria, 2019). 


\subsection{Accounting Practices}

Accounting practice is an example of industrial work practice for vocational students. Noviana (2014)'s research shows that there is a significant influence on work practice experience on job readiness.Work practices in the vocational schools' curriculum have become a tangible form of Dual Education System (Pendidikan Sistem Ganda), namely the implementation of vocational education with planning and implementation of education carried out by forging partnerships between schools and the world of work (Triani \& Arief, 2016).

Accounting practice plays an important role in providing provision for SMK graduates to be able to adapt to the work environment. So it needs training, appropriate learning methods for vocational students to be able to face the world of work. The internship carried out by vocational school students is one of the learning methods for students to add experience and skills to the majors they take. After doing an internship, vocational students can sharpen their desire to work or continue to a higher level of education. The decision making that students make on whether to work or continue studying accounting is influenced by several factors, including the economic condition of the family, willingness or interest, and encouragement from the community.

H1. The vocational internship of the Accounting Department affects job readiness of prospective accountants.

\subsection{Interests in Accounting}

Interest is a high desire for something after going through the process of seeing, observing and comparing it with the desired needs (Senjari, Hasan, \& Sofyan, 2016). Interest can be a factor in influencing a person's decision making. Often interest is also shown from the desire and hard work in achieving certain goals. The achievement of the desired goals is related to efforts to achieve each individual's target. In relation to accounting at vocational schools, the accounting department in several favorite vocational high schools in Salatiga are in demand; at SMK Negeri 1 Salatiga, three classes of accounting majors are opened with an average number of students per class of 35 students.

The average selection of an accounting major is based on the ease of finding jobs and interest in becoming an accountant (Iswahyuni, 2018). Students who are interested in choosing accounting majors will find it easier to absorb knowledge in the learning process so that they will be sufficiently equipped to do an internship and enter the world of work. The high demand for accounting graduates can also be seen from the choice of concentration for students at SMK.
Increasingly fierce competition makes vocational schools compete to determine a curriculum that can increase the professionalism of their graduates to become accountants.

$\mathrm{H} 2$. Students' interest in accounting has an influence on job readiness of prospective accountants.

\subsection{Motivation in Accounting}

Motivation to learn accounting can be done by applying the principles of basic accounting calculations, namely addition, subtraction, multiplication and division (Dewi \& Sawarjuwono, 2019). The enthusiasm to explore accounting since secondary schools (SMA or SMK for Indonesian) can arise from the information obtained about careers in the world of accounting which is at the wide range (Nurniah \& Nasir, 2017). The emergence of motivation to learn accounting material has a significant effect on a person in continuing their education in accounting to a higher level even at the professional level (Febrianty \& Ikbal, 2016). One of the determinants of a career path is the choice of the chosen major. Selection of majors should be in accordance with the interests and abilities of students, because the appropriate majors will increase motivation to study the material obtained (Pramiudi \& Setiawan, 2018). In addition, to motivate students to understand accounting theory better, it can be done by providing practicum teaching materials on productive subjects that simulate students such as facing real cases in accounting (Ambarsari, Santoso, \& Ivada, 2017).

H3. The motivation that the students in the Accounting Department possess has an effect on job readiness of prospective accountants.

\section{RESEARCH METHOD}

The method used in this study uses a quantitative approach. This study used a Likert scale for each variable used. The method used in this research is descriptive analysis technique and multiple linear regression. The independent variables used were (X1) accounting practice, (X2) student interest, and (X3) motivation. Meanwhile, the dependent variable in this study is (Y) work readiness.

The population used in this study were 3 vocational high schools in the city of Salatiga, namely SMK Diponegoro Salatiga, SMK Negeri 1 Salatiga, and SMK Pelita Salatiga with the total population taken in this study were students of the third grade Accounting Department who had participated in work practices. There are as many as 100 students of SMK Diponegoro, 52 students of SMK Negeri 1, and 8 students of SMK Pelita. 
The method used in determining the sample was purposive sampling, and the respondents were 66 students from three vocational high schools in the city of Salatiga. The criteria used in this study were (1) SMK students majoring in accounting; (2) SMK students who participate in accounting practice activities in their respective schools.

\section{RESULTS AND DISCUSSION}

\subsection{Result}

In this study, some data were collected from questionnaires that had been distributed to several schools in the City of Salatiga. Some of the data including those listed on the questionnaire point are classified in 1). Implementation of industrial work practice activities, 2). Interest in accounting, 3). Motivation in accounting, 4). The level of job readiness of accounting students. The data classification above is processed with the SPSS application and continued by observing the literature review and the development of the hypotheses that are built.

Several other supporting factors, other than active students majoring in accounting as respondents, in this study, were vocational teachers and alumni majoring in accounting as informants. These vocational (SMK) teachers provided additional information about students who stood out in the ability of productive accounting subjects to have an interest in work in the accounting scope. The school gave appreciation to students who have this ability in the form of career counseling on whether to work or continue their studies in accounting. Students who are interested in working after graduating are usually given a recommendation for a place to work from the school as a form of school appreciation for these outstanding students.

\subsubsection{Respondent Characteristics}

Based on the results of tabulation of data obtained from distributing questionnaires to respondents with qualifications (1) Students of the Accounting Department of SMK in Salatiga (2) Students who have participated in accounting work practice activities in their respective schools. The following are the characteristics of the respondents:
Graph 1. Respondent Age

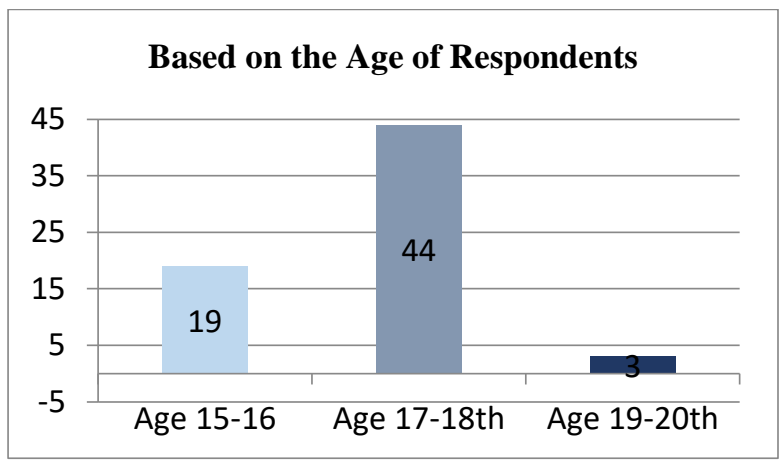

Graph 2. The Gender of Respondent

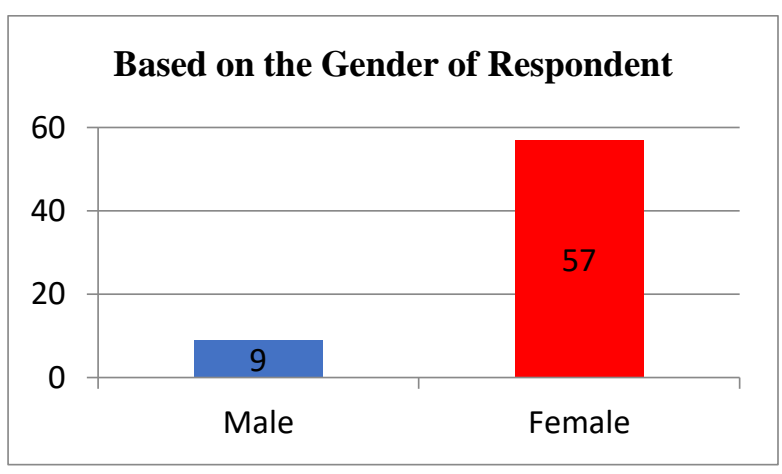

Graph 3. Respondent's Study Interest

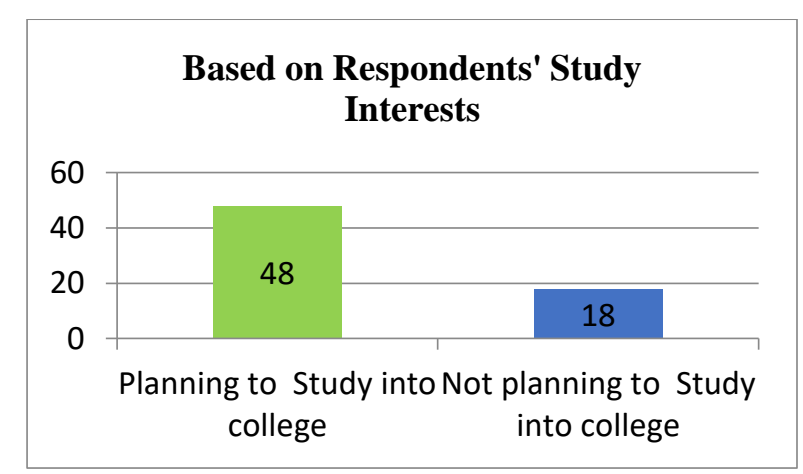


Graph 4. Respondent Characteristics

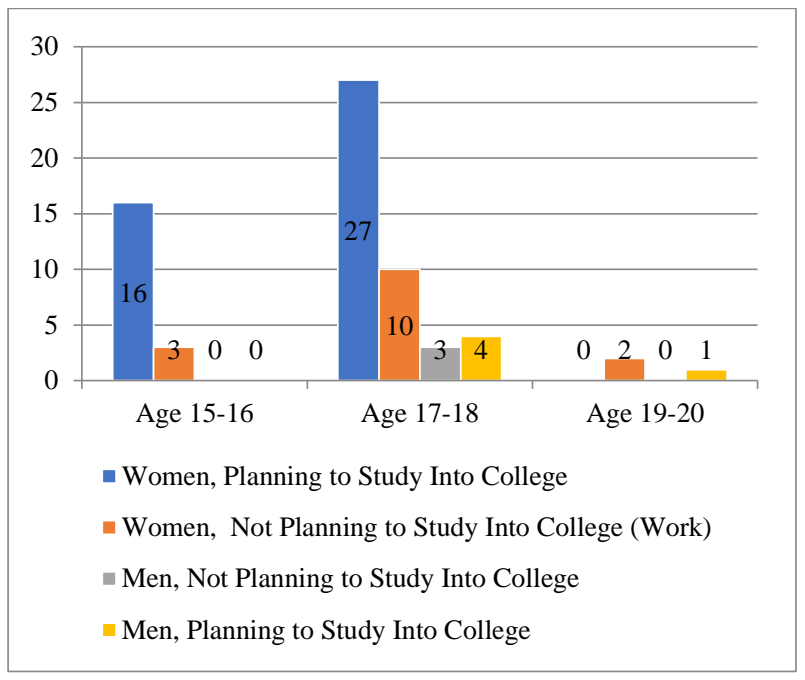

Based on graph 4, it can be concluded that the tendency is that most female students had an interest in continuing their studies to a higher level. Motivation was also thought to strengthen the desire of respondents to realize their dreams as an accountant. On the other hand, male students tended not to continue their studies at a higher level on the grounds that they go to SMKs which produce graduates who are ready to work. The interest of male respondents tended to be low when compared to that of females. Data obtained from the age of respondents was the average age was 17th-18th with the highest age was 20th and the lowest age was 15 th.

\subsubsection{Classical Assumption Test Results}

Based on the results of validity and reliability tests, all questions in the questionnaire were declared valid and reliable at the 5\% significance level. From the output that had been obtained, the Sig. (2-tailed) is 0.701 which means it was greater than 0.05 . Then the data normality test was said to be normal. Based on the test output using SPSS, the results showed that the sig. variable X1 work practice has a value of 0.154 , variable $\mathrm{X} 2$ Interests is 0.273 and variable $\mathrm{X} 3$ is 0.790 which can be concluded that the regression data does contain heteroscedasticity. Based on the output of the multicollinearity test, the VIF value for the X1 Work Practice variable was 1.191 , the X2 Interest variable was 1.994 and the X3 Motivation variable was 2.027, which means that the VIF value is less than 10 , there is no multicollinearity symptom, that is, there is no correlation between the independent variables. Based on the data above, it is said that there is no autocorrelation because the Durbin-Watson value is 1.161 with an explanation of $\mathrm{Du}<\mathrm{d}<4-\mathrm{Du}=1.5079$ $<1.610<2,390$.

\subsubsection{Regression Test Results}

This test was used to determine the significance of each regression coefficient, or to determine the relationship of each independent variable to the dependent variable. In this test, the criteria for the level of sig $<0.05$ and the value of t-count $>\mathrm{t}$-table can be used. The test results can be seen as follows.

Table 1. Regression Test Results

\begin{tabular}{|l|c|c|c|c|c|}
\hline \multirow{2}{*}{ Model } & \multicolumn{2}{|c|}{$\begin{array}{c}\text { Unstandardized } \\
\text { Coefficients }\end{array}$} & $\begin{array}{c}\text { Standardized } \\
\text { Coefficients }\end{array}$ & \multirow{2}{*}{$\mathrm{T}$} & \multirow{2}{*}{ Sig. } \\
\cline { 2 - 5 } & $\mathrm{B}$ & Std. Error & Beta & 2,112 & 0,039 \\
\hline (Constant) & 5,94 & 2,812 & & 1,025 & 0,309 \\
\hline $\begin{array}{l}\text { Accounting } \\
\text { Practices }\end{array}$ & 0,124 & 0,121 & 0,117 & 2,694 & 0,009 \\
\hline Interests & 0,457 & 0,170 & 0,398 & 0,999 & 0,322 \\
\hline Motivations & 0,117 & 0,117 & 0,149 & & \\
\hline
\end{tabular}

Based on the output of the $\mathrm{T}$ test to see the effect of the independent variable on the dependent variable, it can be stated that the $\mathrm{H} 1$ test, the effect of the work practice of accounting students majoring in accounting on the readiness of prospective accountants, it is known from the output that the sig value is 0.309 which means greater than 0.05 , meanwhile t-count is 1.025 which is smaller than t-table which is 1.999 . H1 was rejected because it did not meet the requirements, so it could be stated that work practices in SMK did not affect the readiness of students to become prospective accountants.

In $\mathrm{H} 2$ testing, the influence of interest in accounting students of vocational high school students on the readiness of prospective accountants was obtained from the test output the sig value of 0.009 which is smaller than 0.05 , while for the t-count with a value of 2.694 is greater than the t-table 1.999 . It can be concluded that the second hypothesis is accepted, there is an influence of interest in accounting students of SMK on the readiness of prospective accountants.

Testing H3, the influence of motivation of students majoring in accounting on the readiness of prospective accountants, there obtained the output sig value of 0.322 is greater than 0.05 , while the $t$-count value of 0.999 is smaller than the t-table 1.999, therefore H3 was rejected, there is no effect of student motivation majoring in accounting on job readiness of prospective accountants. 


\section{DISCUSSION}

Based on the research, data obtained showed that field industrial practice or PRAKERIN (praktek kerja industri) and motivation in $\mathrm{H} 1$ and $\mathrm{H} 3$ analysis did not prove that PRAKERIN could affect the readiness of prospective accountants. The non-impact of the practice to work readiness, was caused by several factors, including the selection of an internship in the accounting department that is not suitable and the activities carried that are not in accordance with the accounting field in the research conducted by (Taufik, 2016). Data showed that internship has no significant effect on work readiness of Engineering students at vocational high school. Meanwhile, according to Wardiman in (Taufik, 2016), PRAKERIN is a dual education system that provides space for students to approach the world of work. The simulation of the world of work that is obtained from internship activities can be a reference for students that the theoretical provisions of the school as long as they have not entered the internship period are still lacking so that students feel they are not ready to work as accountants.

In the questionnaire distributed to students, data showed that students who plan to continue their studies in accounting want to explore accounting. Other data obtained was that accounting students majoring in SMK continue their studies in other majors and work. According to the data obtained, some students will work in fields outside of accounting because they feel they have no opportunity and are less interested in accounting. Information obtained from an alumnus of SMK majoring in accounting relates to this data, which states that after graduating the informant did not work in the accounting field. The informant added that during the industrial work practice in SMK, the informant did activities in his practice that were not in accordance with the fields he studied, the informants added that accounting knowledge obtained through high school won't be able to handle real accounting cases in the real world without any sufficient experience. The motivation built for accounting students of vocational high schools encourages students to continue their studies to increase work readiness in the accounting profession. Motivation to be ready to work is created in the final semester students of the Department of Economic Education (Junaidi, Armida, \& Susant, 2018). Dirwanto, 2008 in (Junaidi et al., 2018) states that job readiness is formed not only with motivation and learning achievement but through experience, skills, personal appearance, attitudes, interests and family economic conditions.

H2 data analysis showed that interest can affect job readiness of accounting students majoring in accounting in the accounting profession. In general, interest can increase the enthusiasm of students to explore the theory obtained and students independently seek sources of knowledge in accounting theory and practice. The interest and work readiness of vocational students is influenced by the internship that students have done. Internships can give students consideration to their work readiness. Students who have an interest in their major and are supported by good learning achievement will have high work readiness (Sulistianingsih, Rohman, \& Dalu, 2018). This is supported by several points of questions on the questionnaire which asked that they chose accounting majors on their own accord and it was not a direction or motivation from their parents.

\section{CONCLUSIONS}

The purpose of this study was to analyze accounting practices, student interests and student motivation in increasing readiness to become prospective accountants. From the results of the tests that have been done, it is found that the hypothesis related to accounting practices was rejected, the second hypothesis related to interest is accepted, while the third hypothesis is rejected. Interest in becoming an accountant is believed to optimize the work readiness of the respondents. Personal desire without encouragement from external parties (such as friends, parents, or the environment) tends to be the main reference for respondents to prepare themselves better to become an accountant.

The limitation of this research is the lack of willingness of students in implementing accounting practices at SMK Salatiga. There is still a great need for the role of educators or schools themselves in directing and supervising the internship places so that the implementation of internship activities is more effective and in accordance with their fields, because in this case there are still many answers on the questionnaire that they carry out internship activities that are not in accordance with the field of accounting majors, so what they get when internship does not increase knowledge about accounting practices.

Suggestions for future research are to further develop the suitability of the curriculum with internship so that it can become a reference in school decision making in its implementation. In addition, it is necessary to add a variable of the respondent's financial background, the educational background of the parents, which may also be a supporting variable in the work readiness of accounting students of SMK. 


\section{REFERENCES}

[1]. Agusta, Y. N. (2015). Hubungan Antara Orientasi Masa Depan Dan Daya Juang Terhadap Kesiapan Kerja Pada Mahasiswa Tingkat Akhir Fakultas Ilmu Sosial Dan Ilmu Politik Di Universitas Mulawarman. EJournal Psikologi, 3(11), 369-381. https://doi.org/10.7868/s0032180x15110088

[2]. Ambarsari, R. D., Santoso, S., \& Ivada, E. (2017). Pengembangan Bahan Ajar Praktik Perbankan Untuk Meningkatkan Kompetensi Siswa Pada Pembelajaran Akuntansi Di Smk Negeri 1 Karanganyar. 3(1), 1-13.

[3]. Anna, Y. D., \& Rahayu, S. (2012). The Factors Affected Toward Profession Options as Accountant Public and Non-Accountant Public Selected. SSRN Electronic Journal, 19. https://doi.org/10.2139/ssrn.1867809

[4]. Deswita, A. P., \& Dahen, L. D. (2015). Pengaruh Persepsi Siswa Tentang Gaya Mengajar Guru Dan Minat Belajar Siswa Terhadap Hasil Belajar Akuntansi Pada Program Keahlian Akuntansi Siswa Kelas X Di Smkn 1 Sawahlunto. Economica, 2(1), 110.

https://doi.org/10.22202/economica.2013.v2.i 1.211

[5]. Dewi, S. K., \& Sawarjuwono, T. (2019). Tantangan Auditor Syariah : Cukupkah Hanya dengan Sertifikasi Akuntansi Syariah? 6(1), $17-28$.

[6]. Dockter, D. L. (2012). Problem-Based Learning In Accounting. American Journal of Business Education (AJBE), 5(5), 547-554. https://doi.org/10.19030/ajbe.v5i5.7211

[7]. Ezeagba, C. (2014). The Problems in the teaching and learning of Accounting as a vocational subject in Nigeria Secondary Schools. AFRREV STECH: An International Journal of Science and Technology, 3(2), 208. https://doi.org/10.4314/stech.v3i2.13

[8]. Febrianty, N. D., \& Ikbal, M. (2016). Motivasi Mahasiswa Akuntansi Dan Pengaruhnya Terhadap Minat Untuk Mengikuti Pendidikan Profesi Akuntansi (Studi Empiris Di Fakultas Ekonomi Universitas Mulawarman). Journal of Accounting and Business Education, 1(2). https://doi.org/10.26675/jabe.v1i2.6021

[9]. Firdaus, Z. Z. (2013). Pengaruh unit produksi, pengalaman prakerin dan dukungan keluarga terhadap kesiapan kerja siswa SMK. Jurnal
Pendidikan Vokasi, 2(3), 397-409. https://doi.org/10.21831/jpv.v2i3.1045

[10]. Iswahyuni, Y. (2018). Analisis Faktor-Faktor yang Mempengaruhi Pemilihan Karir Menjadi Akuntan Publik Oleh Mahasiswa Program Studi Akuntansi STIE AKA Semarang. 5(1), 33-44.

[11]. Junaidi, N., Armida, \& Susant, D. (2018). Pengaruh motivasi memasuki dunia kerja dan prestasi belajar terhadap kesiapan kerja mahasiswa jurusan pendidikan ekonomi fakultas ekonomi universitas negeri padang. EcoGen, 1(2), 408-415.

[12]. Maryati, S. (2017). Faktor-Faktor Yang Mempengaruhi Tingkat Pemahaman Akuntansi (Studi Empiris Pada Mahasiswa Akuntansi Ibi Darmajaya Lampung). GEMA, IX, 45-51.

[13]. Mu'ayati. (2014). Pengaruh Praktik Kerja Industri (Prakerin), Penguasaan Mata Diklat Produktif Akuntansi Dan Minat Kerja Siswa Terhadap Kesiapan Menghadapi Dunia Kerja Siswa Smk Program Keahlian Akuntansi Di Smk N 1 Salatiga Tahun Ajaran 2013/2014. 3(2), 327-335.

[14]. Muayati, R., \& Margunani, M. (2014). Pengaruh Praktik Kerja Industri (Prakerin), Penguasaan Mata Diklat Produktif Akuntansi Dan Minat Kerja Siswa Terhadap Kesiapan Menghadapi Dunia Kerja Siswa Smk Program Keahlian Akuntansi Di Smk N 1 Salatiga Tahun Ajaran 2013/2014. Economic Education Analysis Journal, 3(2), 327-335.

[15]. Noviana. (2014). Pengaruh Hasil Belajar Mata Pelajaran Produktif Akuntansi, Program Praktik Kerja Industri Dan Self Efficacy Terhadap Kesiapan Kerja Siswa Kelas Xii Program Keahlian Akuntansi Di Smk Negeri 1 Kendal Tahun Ajaran 2013/2014. Economic Education Analysis Journal, 3(1), 182-190.

[16]. Nurniah, \& Nasir, D. I. B. (2017). Analisis Motivasi Dan Ekspektasi Mahasiswa Dalam Menempuh Pendidikan Tinggi Akuntansi. EKUITAS (Jurnal Ekonomi Dan Keuangan), $19(2), \quad 174$. https://doi.org/10.24034/j25485024.y2015.v1 9.i2.1763

[17]. Permenperin. (2017). Permenperin No 032017.

[18]. Popa, A. F., Stănilă, O. ., \& Ponorîcă, A. G. (2012). Impact of Changes in Methods 
of Teaching and Learning Accounting. The Economic Journal, 2, 110-123. https://doi.org/10.2307/2233838

[19]. Pramiudi, U., \& Setiawan, B. (2018). Penelusuran Persepsi Mahasiswa Atas Program Studi Akuntansi dan Minat Studi Lanjut. 2, 103-113.

[20]. Satria, M. R. (2019). Pemilihan Jalur Karir bagi Mahasiswa Akuntansi di Politeknik Pos Indonesia. 13(2), 125-133.

[21]. Senjari, R., Hasan, A., \& Sofyan, A. (2016). Pengaruh Motivasi, Lingkungan Kerja dan Nilai Sosial Terhadap Minat Mahasiswa Akuntansi dalam Memilih Karir Sebagai Akuntan Publik. Jurnal Online Mahasiswa Fakultas Ekonomi Universitas Riau, 3(1), 133-147.

[22]. Sulistianingsih, A., Rohman, M., \& Dalu, Z. C. A. (2018). Peran minat kerja dan prestasi belajar terhadap kesiapan kerja siswa smk. Jurnal Media Komunikasi Pendikan Teknologi Dan Kejuruan 51 PERAN, Vol.5(No.2), 51-60.

[23]. Susanti, S., Rispantyo, \& Kristianto, D. (2017). Pengaruh Minat Belajar, Perilaku Belajar, Kecerdasan Intelektual Dan Kecerdasan Emosional Terhadap Tingkat Pemahaman Akuntansi. 127-134.

[24]. Taufik, I. (2016). Pengaruh Prakerin erhadap kesiapan kerja siswa. Jurnal
Pendidikan Vokasional Teknik Mesin, 4(1), 55-60.

[25]. Triani, D., \& Arief, S. (2016). Pengaruh Praktik Kerja Industri, Hasil Belajar Mata Pelajaran Akuntansi, Dan Motivasi Memasuki Kerja Terhadap Kesiapan Kerja Siswa Akuntansi. Economic Education Analysis Journal, 5(3), 849-849.

[26]. Yunanda, R. A., \& Majid, N. B. A. (2011). The contribution of Islamic ethics towards ethical. Issues in Social and Environmental Accounting, 5(1), 124-137. 